\title{
Application of direct PCR in rapid rDNA ITS haplotype determination of the hyperparasitic fungus Sphaeropsis visci (Botryosphaeriaceae)
}

\author{
Ildikó Varga ${ }^{1 \dagger}$, Péter Poczai $^{1,3^{*}+}$, István Cernák ${ }^{2}$ and Jaakko Hyvönen ${ }^{1}$
}

\begin{abstract}
Background: The plant pathogenic fungus, Sphaeropsis visci a dark-spored species of Botryosphaeriaceae, which causes the leaf spot disease of the European mistletoe (Viscum album). This species seems to have potential as a tool for biological control of the hemiparasite. For the rapid detection of S. visci haplotypes we tested a direct PCR assay without prior DNA purification. This approach was based on a polymerase enzyme from the crenarchaeon Sulfolobus solfataricus engineered by fusion protein technology, which linked the polymerase domain to a sequence non-specific DNA binding protein (Sso7d).
\end{abstract}

Findings: Most isolates of Sphaeropsis visci grouped together in our phylogenetic analyses, indicating that isolates had a previously reported haplotype sequence, which is commonly found in the analyzed Hungarian population. This haplotype was also reported from diseased mistletoe bushes from other European countries. We further identified unique single nucleotide polymorphisms (SNPs) in the ITS region, which were specific to the only well resolved clade in the phylogenetic analysis.

Conclusions: The diPCR approach allowed amplification of ITS rRNA gene directly from small amounts of fungal samples without prior DNA extraction. This simple bioassay in plant disease management enables collection of genomic data from fungal plant pathogen populations.

Keywords: Biological control; Botryosphaeriaceae; diPCR; European mistletoe (Viscum album); Genotyping; Polymerase inhibitors; Sphaeropsis visci

\section{Introduction}

The hyperparasitic fungal plant pathogen [Sphaeropsis visci (Alb. \& Schwein.) Sacc.], which causes leaf spot disease of European mistletoe (Viscum album L.) seems to have potential as a tool for biological control of this hemiparasite (Varga et al. 2012a; Karadžić et al. 2004; Fischl 1996; Stojanović 1989). Three to six weeks after inoculation the fungal infection spreads all over the leaves, branches and berries; a few months later the whole shrub becomes dark yellow and necrotic. Sphaeropsis visci (Basionym: Sphaeria atrovirens var. visci Alb. \& Schwein.,

\footnotetext{
* Correspondence: peter.poczai@gmail.com

${ }^{\dagger}$ Equal contributors

'Plant Biology, Department of Biosciences, University of Helsinki, PO Box 65, Helsinki Fl-00014, Finland

${ }^{3}$ Botanical Museum, University of Helsinki, PO Box 7, Helsinki Fl-00014, Finland

Full list of author information is available at the end of the article
}

Consp. fung. (Leipzig): 48. 1805. = Phaeobotryosphaeria visci (Kalchbr.) A.J.L. Phillips \& Crous, Persoonia 21: 47. 2008. For synonyms see (Phillips et al. 2013)) is a darkspored ascomycete of the family Botryosphaeriaceae (Figure 1). The connection between the asexual and sexual morph of the fungus was established by Phillips et al. (Phillips et al. 2008) by the discovery that the ascomycete Phaeobotryosphaeria visci occurring on Viscum album produces conidia typical of Sphaeropsis visci. Phillips et al. (Phillips et al. 2008) applying a one fungus one name concept chose Phaeobotryosphaeria in favor of Sphaeropsis. However, the $18^{\text {th }}$ Botanical Congress adopted the Melbourne Code (McNeill et al. 2012) ratifying that priority of names will no longer be based on the life stage of fungi. Thus, the older name Sphaeropsis (1880) took priority over Phaeobotryosphaeria (1908). The corrections and new name combinations were described in Phillips et al. (Phillips et al. 2013). 


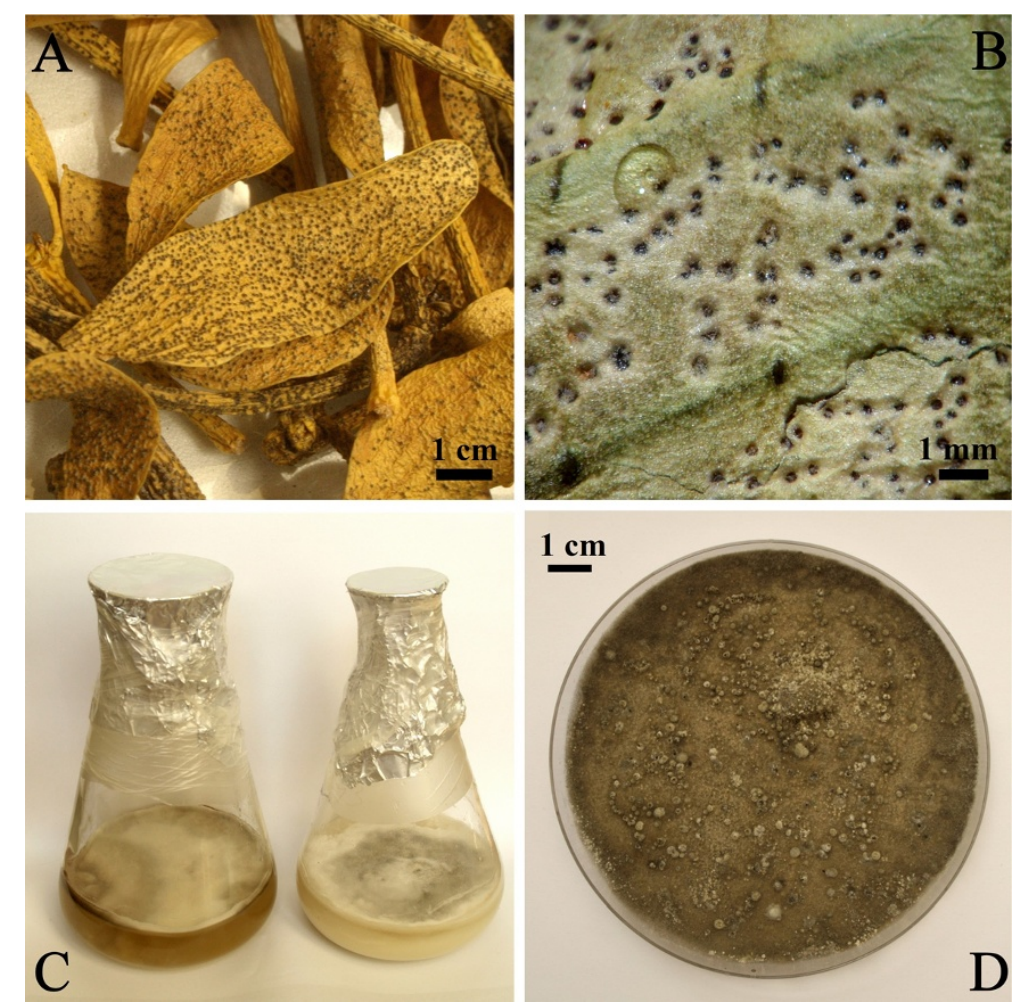

Figure 1 Leaf spot disease on European mistletoe (Viscum album) caused by Sphaeropsis visci (A, B) and culture characteristics of the fungus (C, D). A. Symptoms of late infection on: mistletoe leaves and twigs are showing chlorosis. B. Symptoms after 20 days of infection; superficial pycnidia are evident on leaves. C. S. visci liquid culture in potato dextrose (left) and oatmeal broth (right). D. S. visci culture on oatmeal agar showing dark grey pigmentation.

The successful control of the European mistletoe would be desirable as it causes considerable damages in many forests and orchards (Baltazár et al. 2013). This causes large economic losses in forestry and agriculture because infected wood becomes unsuitable for processing and infected trees are predisposed to other infections. Mistletoe increases tree mortality and contributes to forest decline (Tsopelas et al. 2004; Idžojtić et al. 2008). With the global warming this might become a more serious problem of larger economic importance. Viscum album subspecies do not reach the northern altitudinal limits of their host trees yet (von Tubeuf 1923) as they are temperature-sensitive (Skre 1979; Jeffree and Jeffree 1996). Paleo-climatological studies have used mistletoes as climate indicators (Iversen 1944) as the mean monthly temperatures of the coolest (January) and the warmest month (July) strictly limit the occurrence of V. album (Skre 1979). Temperature increase in these months would allow mistletoes to extend their northern latitudinal occurrence. The upper elevation limit of pine mistletoe (Viscum album subsp. austriacum) in the Rhone Valley of Switzerland rose $200 \mathrm{~m}$ in the past century, and during this period the mean winter temperature increased by $1.6^{\circ} \mathrm{C}$ (Dobbertin et al. 2005).
The host plant, Pinus sylvestris L., has suffered high mortality in these alpine valleys (Bigler et al. 2006) and pine mistletoe contributed to tree death in this area (Dobbertin and Rigling 2006).

Currently the best method to control mistletoe is to cut off infected branches of the host trees. However, mistletoe cannot be removed completely because it forms adventive shoots from the cortical strands below the cambium of the host (Zuber 2004; Varga et al. 2012b). In order to develop Sphaeropsis visci as an effective bio-control agent against Viscum album more information is needed about the epidemiology, population biology and the existence of possible haplotypes of this fungus. Fungal biological control agents (BCAs) must perform well in the field tolerating wide range of climatic conditions (fluctuating temperatures, humidities, UV light), edaphic (soil types) and biotic (antagonistic) factors (Butt and Copping 2000). One of the major criticism of fungal BCAs is that they act slowly, therefore factors determining pathogen virulence should be identified and used in strain selection and quality control (Butt and Copping 2000). Cultural conditions must be identified, which retain virulence without increasing production costs. At present little progress has been made in this area 
with $S$. visci, however, there are efforts to identify optimal growth conditions (Varga et al. 2012c, 2013).

For haplotype determination PCR-based target DNA detection with universal barcode regions is a simple way to identify different haplotypes of plant pathogenic fungi (Queloz et al. 2011; Boose et al. 2011). However, typical PCR protocols require an initial DNA isolation step which is often time-consuming and involves expensive kits or reagents. The isolation of fungal cultures from host plants, again, might be very slow and laborious.

The application of direct PCR (diPCR) allows amplifications without any prior DNA extraction. This is based on recent advances in enzyme technology which has resulted in the increased performance of DNA polymerases in vitro. $\mathrm{PCR}$ in general tries to mimic the in vivo DNA replication, but it is much slower, less efficient, and prone to many errors. Wang et al. (Wang et al. 2004) developed a fusion protein technology by linking the polymerase domain to a sequence non-specific DNA binding protein (Sso7d) from the crenarchaeon Sulfolobus solfataricus Zillig et al. (Zillig et al. 1980). This polymerase is reported to lead to a 25-fold lower error rate as compared to common Thermus aquaticus Brock \& Freeze (Taq) polymerase (Wang et al. 2004). Besides a huge increase in efficiency, fusion polymerases are resistant to various PCR inhibitors and have faster overall performance (André 2009). This technology opens possibilities to develop rapid diagnostic methods (e.g., haplotype and species determination) for plant pathogenic fungi by omitting the DNA purification step.

Here we present the application of a diPCR-based assay for the rapid and specific detection of Sphaeropsis visci haplotypes without prior DNA purification. The PCR assay amplifies the internal transcribed spacer (ITS) region of the nuclear ribosomal RNA gene. This region is widely used in fungal taxonomy, and used also to identify haplotypes of plant pathogenic fungi (Coates et al. 2002; Kiss et al. 2011; Nechwatal and Mendgen 2009; Bakonyi et al. 2006).

\section{Methods}

\section{Sample collection}

Infected European mistletoe leaves were collected in 2010 and preserved as dry herbarium samples. Sampling was conducted in the western part of Hungary where Sphaeropsis visci is commonly found. Sequences from reference strains deposited in MycoBank (mycobank.org) and GenBank (Benson et al. 2011) were also included in the study (Table 1).

\section{Direct PCR (diPCR) and sequencing}

Excised pycnidia from surface sterilized (1\% sodium hypochlorite for $20 \mathrm{~min}$ ) mistletoe leaves were lysed in $20 \mu \mathrm{l}$ Dilution Buffer and crushed with pipette tips in Eppendorf tubes. The samples were incubated at room temperature for $5 \mathrm{~min}$; then $0.6 \mu \mathrm{l}$ of the supernatant was used as template for PCR amplification. PCR was performed with undiluted and diluted DNA extracts from Sphaeropsis visci templates including $10 \mathrm{ng}$ to as low as $0.1 \mathrm{pg}$ DNA. DNA was quantified by using a Qubit fluorometer. The amplification was performed with the primers ITS1 (5'-TC CGTAGGTGAACCTGCGG-3') and ITS4 (5'-TCCTC CGCTTATTGATATGC-3') designed by White et al. (White et al. 1993) for the fungal Internal Transcribed Spacer (ITS) region of the ribosomal RNA gene. Following the protocol of the Phire Plant Direct PCR Kit, amplification reactions, which were performed in $20 \mu \mathrm{l}$ volume containing: $7 \mu \mathrm{l}$ nuclease free water, $0.6 \mu \mathrm{l}$ sample (from dilution protocol), $0.5 \mu \mathrm{M}$ of each primer, $10 \mu \mathrm{l}$ of $2 \times$ Phire Plant PCR buffer and $0.4 \mu$ of Phire Hot Start II DNA Polymerase. All PCR reactions were performed using the following program: $5 \mathrm{~min}$ at $98^{\circ} \mathrm{C}$ for initial denaturation, 40 cycles of $5 \mathrm{~s}$ denaturation at $98^{\circ} \mathrm{C}, 5 \mathrm{~s}$ annealing at $54^{\circ} \mathrm{C}$, and $20 \mathrm{~s}$ extension at $72^{\circ} \mathrm{C}$, followed by

Table 1 Details about isolates, species and their respective host used in the present study

\begin{tabular}{|c|c|c|c|c|c|}
\hline Taxon & Sample code & Host & Locality & GenBank accession number & Reference \\
\hline Sphaeropsis visci & Pheo1-20 & Viscum album & Hungary & JQ291707-JQ291726 & This study \\
\hline Sphaeropsis visci & Pheo21-30 & Viscum album & Hungary & KC759681-KC759690 & Varga et al. (2012a) \\
\hline Sphaeropsis visci & CBS186.97 & Viscum album & Germany & EU673325 & Phillips et al. (2008) \\
\hline Sphaeropsis visci & CBS100163 & Viscum album & Luxembourg & EU673324 & Phillips et al. (2008) \\
\hline Sphaeropsis visci & CBS122526 & Viscum album & Ukraine & EU673326 & Phillips et al. (2008) \\
\hline Sphaeropsis visci & CBS122527 & Viscum album & Ukraine & EU673327 & Phillips et al. (2008) \\
\hline \multicolumn{6}{|l|}{ Outgroups } \\
\hline Sphaeropsis citrigena & None & Citrus sinensis & New Zealand & EU673328 & Phillips et al. (2008) \\
\hline Sphaeropsis citrigena & None & Citrus sinensis & New Zealand & EU673329 & Phillips et al. (2008) \\
\hline Phaeobotryon mamane & None & Sophora chrysophylla & Hawaii & EU673331 & Phillips et al. (2008) \\
\hline Botryosphaeria dothidea & None & Prunus sp. & Switzerland & AY236949 & Slippers et al. (2004) \\
\hline Diplodia cupressi & None & Cupressus sempervierns & Israel & DQ458893 & Alves et al. (2006) \\
\hline
\end{tabular}


a final extension for $1 \mathrm{~min}$ at $72^{\circ} \mathrm{C}$. Products were analyzed by gel electrophoresis in $1.5 \%(\mathrm{w} / \mathrm{v})$ agarose gels (RESolute Wide Range, BIOzym) with $0.5 \times \mathrm{TBE}$ electrophoresis buffer $(89 \mathrm{mmol} / \mathrm{l}$ Tris $\mathrm{HCl}, 89 \mathrm{mmol} / \mathrm{l}$ boric acid, $2 \mathrm{mmol} / \mathrm{l}$ EDTA) at $120 \mathrm{~V}$ for $1 \mathrm{~h}$ and visualized by post-staining with ethidium bromide. The clean-up of PCR products was performed by removing non-incorporated primers with $10 \mathrm{U}$ exonuclease I and degradation of nucleotides by $1 \mathrm{U}$ thermosensitive alkaline phosphatise (Exo I and FastAP, Fermantas, Lithuania). PCR mixes were incubated at $37^{\circ} \mathrm{C}$ for $15 \mathrm{~min}$ and the reaction was stopped by heating the mixture at $85^{\circ} \mathrm{C}$ for $15 \mathrm{~min}$. Excised fragments were cleaned with NucleoSpin Extract II Kit (Machery-Nagel, Germany). Sequencing was performed in an ABI 3130XL automated sequencer in both directions using the ITS1 and ITS4 primers and the ABI PRISM BigDye Terminator Cycle Sequencing Ready Reaction Kit v.3.0.

\section{Sequence assembly and alignment}

Forward and reverse sequence reads for all isolates were assembled with CodonCode Aligner v.3.7.1. (codoncode. org). Discrepancies were manually resolved by editing the traces using the compare option of the advanced assembly function. Single consensus sequences were extracted in FASTA format from the compared assemblies. Multiple sequences were aligned with MUSCLE (Edgar 2004) as implemented in Geneious v.4.8.5 (geneious.com) using default settings. Ribosomal exons and spacer regions were annotated in the alignments using the fungal reference sequences deposited in the ITS2 database (http://its2. bioapps.biozentrum.uni-wuerzburg.de/). Obtained sequences were compared with sequences available in GenBank database using the basic local alignment search tool
(BLAST). All sequences were annotated and deposited in GenBank (Benson et al. 2011) under accession numbers JQ291707-JQ291726 (Table 1).

\section{Phylogenetic analysis}

Multiple outgroups were included in the phylogenetic analyses based on our previous morphological and molecular identification (Varga et al. 2012a). These were selected from closely and more distantly related clades of Botryosphaeriaceae following Phillips et al. (Phillips et al. 2008). Outgroups included the closely related taxon S. citrigena (AJL Phillips, PR Johnst. \& Pennycook) AJL Phillips \& A Alves, Phaeobotryon mamane Crous \& AJL Phillips from the sister clade, Botryosphaeria dothidea (Moug.) Ces. \& De Not. from the more basal branch, and one representative of the distantly related Diplodia cupressi AJL Phillips \& A Alves from the same family. We supplemented our samples with sequences from other samples of $S$. visci used in our previous study (Varga et al. 2012a).

\section{Parsimony analysis}

Before making phylogenetic analysis with parsimony as an optimality criterion we were able to reduce the size of the matrix to include only 12 terminals due to numerous, completely identical, duplicates. Due to the small size of the effective matrix we were able to make analysis using the ie command of the program TNT (Goloboff et al. 2008) that ensures finding (all) the most parsimonious tree(s). Jackknife (Farris et al. 1996) support values were calculated using 100 replications with the same search algorithm (ie) as in the search for the parsimonious tree(s).

A
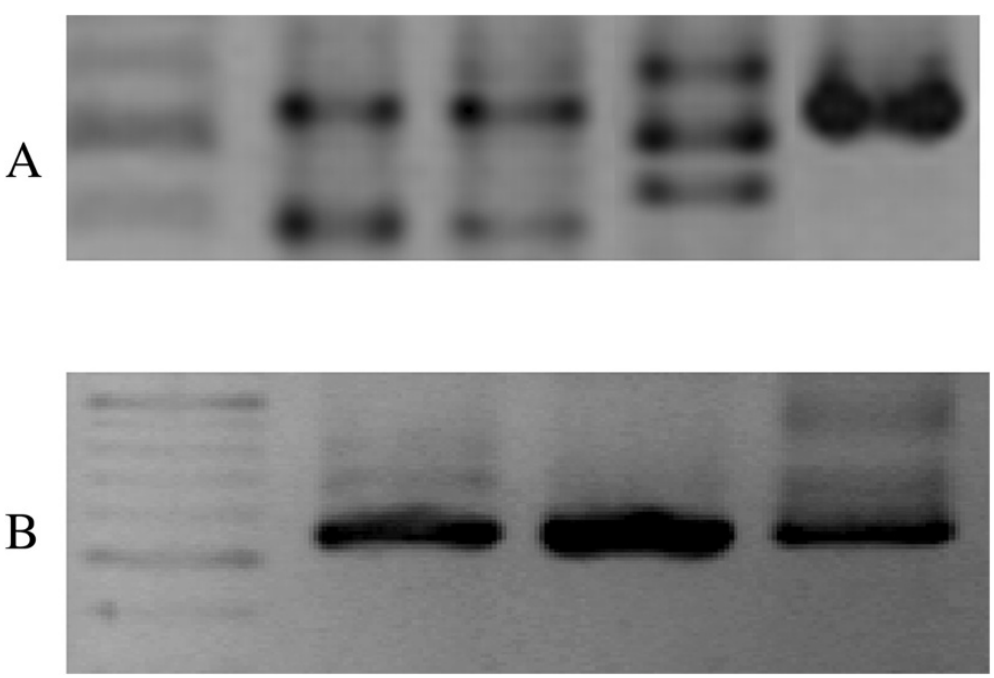

Figure 2 PCR products from diPCR amplification. A. Products resulting from fungal contamination. The first line is the size marker indicating 400 to $600 \mathrm{bp}$ range. B. Amplified $560 \mathrm{bp}$ size ITS fragments of Sphaeropsis visci. 


\section{Bayesian analyses}

Bayesian analysis was performed with MrBayes v3.2 (Huelsenbeck and Ronquist 2001). The HasegawaKishino-Yano model (HKY) nucleotide substitution model was selected with jModelTest 2 (Darriba et al. 2012) using the Akaike information criterion (AIC) for the dataset. We attempted to sample all trees that have a reasonable probability given the assembled datasets using the Metropolis-coupled Markov chain Monte Carlo (MC) ${ }^{3}$ method. Analyses were initiated with four runs and four chains $\left(8 \times 10^{6}\right.$ generations each). We sampled every $10,000^{\text {th }}$ generation to reduce the size of output files and make the samples more independent. Simulations were run until stationarity was reached assessed according to the average standard deviation of split frequencies $<0.01$. $\mathrm{MC}^{3}$ convergence was explored by examining the Potential Scale Reduction Factor (PSRF) for all parameters in the model and plots of loglikelihoods over time together with other plots for all parameters allowed by Tracer v1.5 (http://tree.bio.ed.ac. $\mathrm{uk} /$ software/tracer/). Additional tests of convergence were conducted with the online program AWTY (Nylander et al. 2008) using the 'cumulative' and 'compare' functions. The states of the chains sampled before stationarity (split freq. > 0.01) were discarded as burn-in (25\%). Trees from BI analyses were summarized as majorityrule consensus trees and edited with TreeGraph2 (Stöver and Müller 2010).

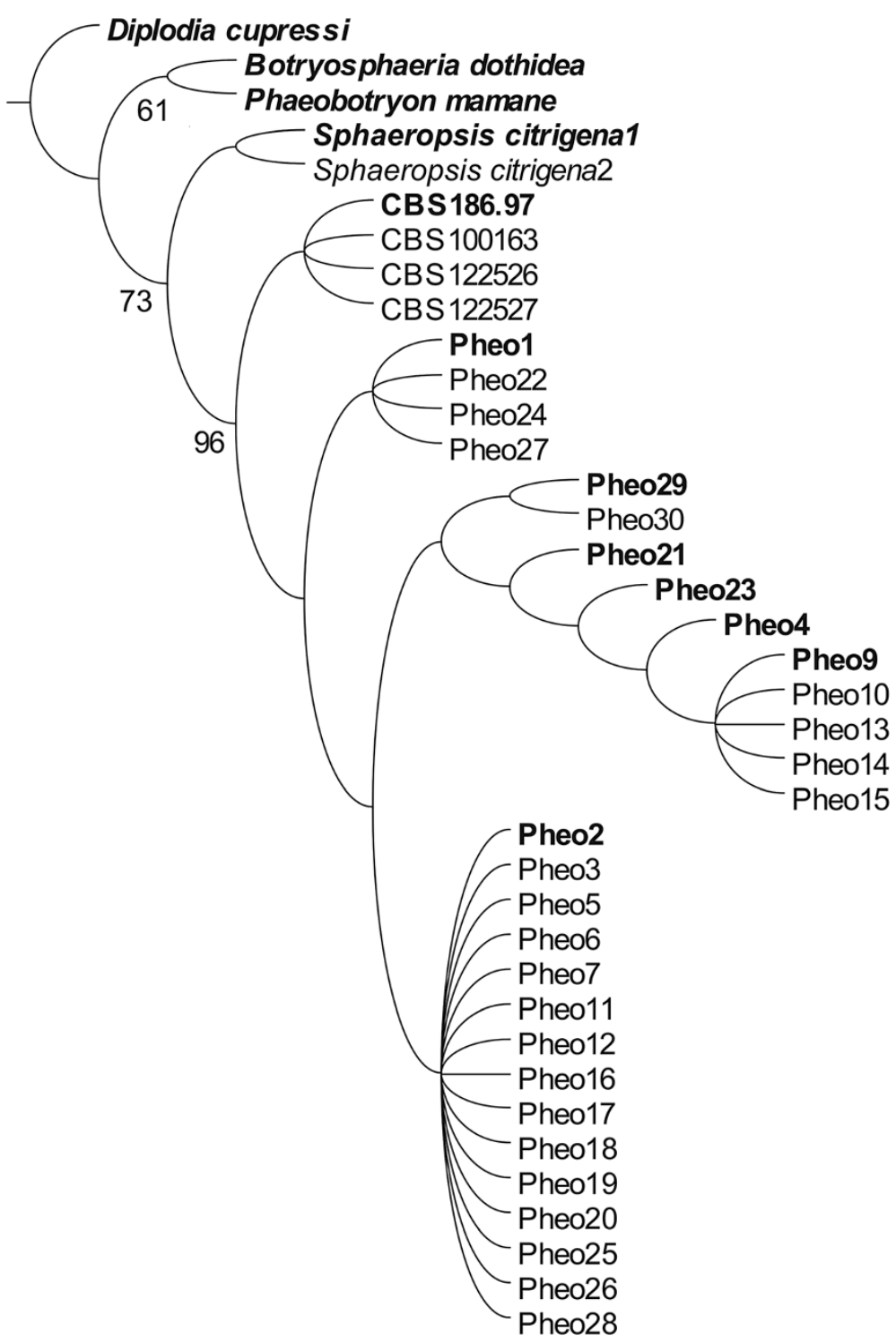

Figure 3 Most parsimonious tree found by the phylogenetic analysis. The tree was calculated from 12 (in bold) covering the whole sequence variability. Identical sequences were added to the final tree. Numbers above branches represent jackknife support values. 


\section{Results and discussion}

The results show that all tested amounts of template were sufficient to produce amplicons around $560 \mathrm{bp}$ long. However, amplifications with lower concentrations produced only faint bands on agarose gels (data not shown). The analytical sensitivity of diPCR was proved to be high with lower concentrations of DNA that are close (ca. 0.1 $\mathrm{pg}$ ) to the content of a single fungal cell that is reported to be around ca. 0.15 pg per cell (Kim et al. 2000). This is not surprising as the ITS region is present in multiple copies arranged in tandem repeats in most eukaryotic organisms (Poczai and Hyvönen 2010). In a few cases we detected other fragments of different size in the gel electrophoresis (Figure 2A). All these fragments were excised from the gels and sequenced together with Spaheoropsis. visci bands of the expected size of $560 \mathrm{bp}$. Sequencing and NCBI BLAST search confirmed that products of deviating size belong to the common airborne fungal taxa (Kano et al. 2004) Cryptococcus magnus (Lodder \& Kreger-van Rij) Baptist \& Kurtzman or Fusarium sp. with 100\% sequence match (sequences not provided but available from the authors upon request). In some cases we also detected larger faint bands ( $750 \mathrm{bp})$ but we were unable to extract them from the gels for sequencing. We anticipate these amplicons were generated from the host (Viscum album) as different combinations of the primer set described by White et al. (White et al. 1993) are also used to amplify ITS fragments from European mistletoe (Zuber and Widmer 2000). If additional products are present, fragments showing the expected size should be excised from gels also exemplified by our study. For successful sequencing almost all targeted $S$. visci amplicons were excised from the gels. This requires some additional equipment and time than to simply clean PCR products with exonuclease and phosphatase enzymes. This is contrary to the findings of Aranyi et al. (Aranyi et al. 2014) who used the same approach to identify formae speciales (f.sp.) of powdery mildew [Blumeria graminis (DC.) Speer]. The lack of plant ITS fragments in their case could be attributed the fact that powdery mildew mycelia could be easily collected from the leaf surface, while pycnidia of S. visci are highly embedded in the plant tissues.

We also recommend surface sterilization of the diseased plant leaves and the use of laminar air flow hoods to perform sampling and to set up the PCR when working with plant pathogenic fungi. Direct PCR can be problematic when the contaminant generates amplicons same size as the target region. During our experiments we did not experience such amplicons, but in such cases other laboratory procedures should be applied to obtain satisfactory results e.g. cloning the fragments.

Parsimony analysis of the matrix of the 12 terminals and 15 parsimony informative characters resulted in one parsimonious tree with a length of 21 steps (Figure 3). Consistency (CI, (Kluge and Farris 1969)) and retention indices (RI, (Farris 1989)) were 0.71 and 0.75, respectively. The results of the two Bayesian runs conducted with MrBayes were highly congruent with each other. PSRF values averaged 1 , strongly suggesting that stationarity had been reached. The comparison of the topologies and associated posterior probability values obtained across the independent runs for the dataset with AWTY verified convergence. The inspection of the log likelihood trace plot and the comparison of each run also showed that the runs reached stationarity (Figure 4 ) after $8 \times 10^{5}$ generations. Both Bayesian and parsimony analyses strongly supported a separate clade composed only by Sphaeropsis visci isolates (Figure 5). Branch lengths of the phylogenetic trees indicated a low level of genetic variation among the isolates. Closer inspection of the aligned sequences revealed only a limited number of single nucleotide polymorphisms (SNPs) among the terminals. In the Bayesian analysis internal groups of $S$. visci collapsed on the majority rule consensus tree as the posterior probability of
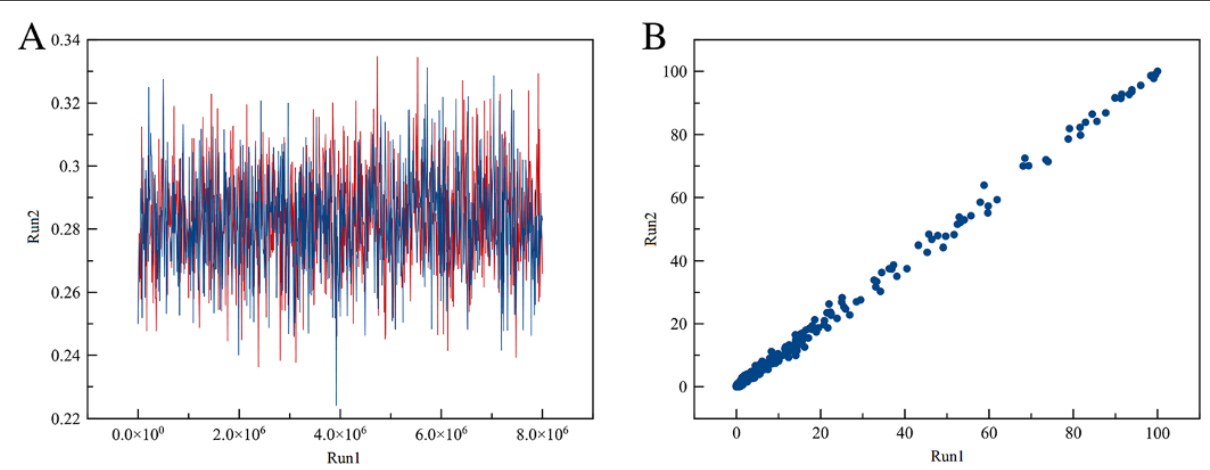

Figure 4 Examples of output from AWTY. The plots show the partial graphical exploration of the output from the four different runs of the dataset analyzed in MrBayes v.3.2. A. The first graph is the trace plot of the log likelihood (InL) and the sampled values. Blue and red traces indicate run1 and run2, while burn in is not shown on the plots. B. AWTY bivariate plot of the split frequencies for comparison between paired Bayesian MCMC simulations from MrBayes analyses. The high correlation shows convergence of the runs. 


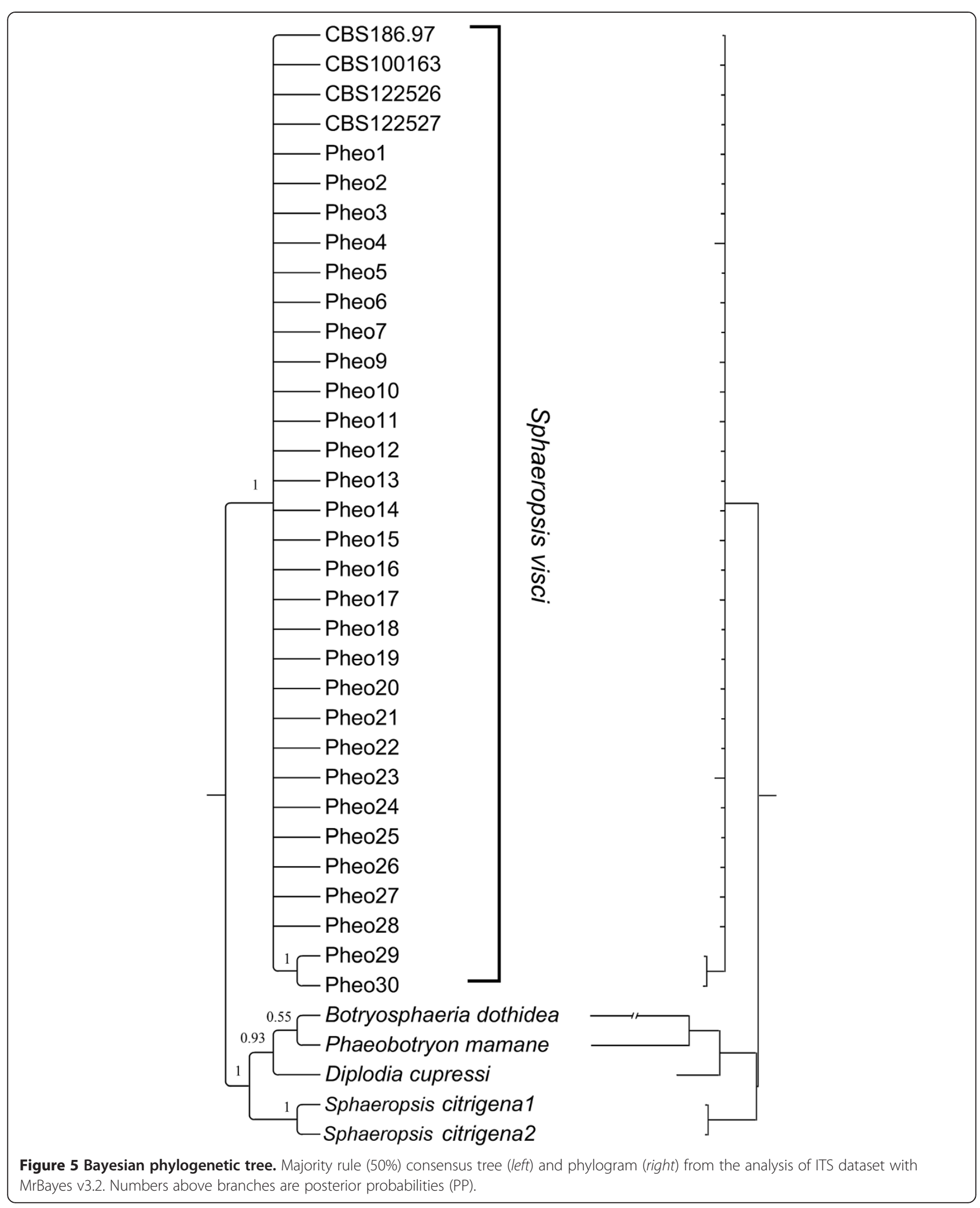

these clades were weak. The detected SNPs were not informative enough to separate them with high posterior probability (PP) values.
A critical trait of pathosystems established in plant populations is the degree to which the same pathogen populations are present and dispersed in the field. The 
phylogenetic analysis revealed that the majority of the isolates from our study fall in the same group with strains reported in previous studies (Varga et al. 2012a; Phillips et al. 2008). This indicates that there is a widely distributed haplotype that is predominant in Sphaeropsis visci populations in Hungary. It has a common ITS sequence matching with sequences known from other countries in Europe (Phillips et al. 2008). Sphaeropsis visci is a hyperparasitic pathogen with reported anamorphic reproducing affinity (Phillips et al. 2008). However, we currently know very little about the reproductive biology of this pathogen. Teleomorphs of this species are rarely found and the connection between Phaeobotryosphaeria visci and its anamorph Sphaeropsis visci was only recently shown (Phillips et al. 2008). The presence of different ITS types in the population could be attributed to sexual recombination as shown by Ahvenniemi et al. (Ahvenniemi et al. 2009) for Rhizoctonia solani JG Kühn. However, during our large scale field survey conducted in Hungary during 2010 (Varga et al. 2014) we were unable to find P. visci teleomorphs on Viscum album. Clonality of this species' life cycle reduced variation in the analyzed population but this may increase among population, if migration is low. In the absence of high levels of gene flow, local selective sweep will remove variation within populations but will not remove variation between populations (Rydholm et al. 2006). This should be investigated in detail by further large scale analyses sampling further populations of Hungary. Such analysis of the population genetic structure of this hyperparasitic fungus is under way and would be crucial to understand the dynamics of such pathosystems.

\section{Summary}

The diPCR approach presented allows amplification of rDNA ITS bands directly from small amounts of fungal samples without prior DNA extraction. The method reduces the time needed for sample processing and simplifies the workflow for plant pathogenic fungal haplotype analyses. In the traditional ITS analysis DNA from the isolates is obtained by performing, in some cases quite challenging, fungal culturing. Some fungal samples may also contain components which interfere with PCR. As shown here, these culturing steps can be avoided by using the direct PCR method and the problems caused by the presence of PCR inhibitors on the other hand can be avoided by dilution of the template. In summary, the direct PCR method offers a fast and simple bioassay in plant disease management and enables collection of genomic data from fungal plant pathogen without the need to cultivate them.

\section{Availability and requirements}

Project name: Hyperparasitic fungal biocontrol agent against European mistletoe.
Project home page: http://tuhat.halvi.helsinki.fi/portal/ en/person/poczai

Other requirements: none

License: none

Any restrictions to use by non-academics: none

\section{Competing interests}

The authors declare they have no competing interests.

\section{Authors' contributions}

IV collected the samples and prepared microphotographs. IC and PP conducted PCR while sequencing was carried out by IV and PP. JH and PP performed the phylogenetic analyses. The manuscript was drafted by IV and PP. It was revised and approved by all authors.

\section{Acknowledgments}

This research represents a partial fulfilment of the requirements for the degree of Doctor of Philosophy (PhD) awarded to Ildikó Varga in

Phytopathology and Plant Protection in the University of Pannonia, Hungary. This study was supported by a Hungarian Eötvös Fellowship Grant provided to IV. PP gratefully acknowledges support from a Marie Curie Fellowship Grant (PIEF-GA-2011-300186) under the seventh framework program of the European Union. IC is supported by the János Bolyai Research Fellowship of the Hungarian Academy of Sciences.

\section{Author details}

${ }^{1}$ Plant Biology, Department of Biosciences, University of Helsinki, PO Box 65 Helsinki Fl-00014, Finland. ${ }^{2}$ Potato Research Centre, Centre of Agricultural Sciences, University of Pannonia, Festetics u. 7, Keszthely H-8360, Hungary. ${ }^{3}$ Botanical Museum, University of Helsinki, PO Box 7, Helsinki Fl-00014, Finland.

Received: 4 February 2014 Accepted: 8 July 2014

Published: 30 September 2014

\section{References}

Ahvenniemi P, Wolf M, Lehtonen MJ, Wilson P, German-Kinnari M, Valkonen JPT (2009) Evolutionary diversification indicated by complex base changes in ITS2 secondary structures in a complex fungal species, Rhizoctonia solani. J Mol Evol 69:150-163

Alves A, Correia A, Phillips AJL (2006) Multi-gene genealogies and morphological data support Diplodia cupressi sp. nov., previously recognized as D. pinea f.sp. cupressi, as a distinct species. Fungal Divers 23:1-15

André C (2009) New develpoments in PCR. BioTechniques 46:375-376

Aranyi NR, Varga I, Poczai P, Cernák I, Vida G, Molnár-Láng M, Hoffmann B (2014) What types of powdery mildew can infect wheat-barley introgression lines? Eur J Plant Pathol 139:119-25

Bakonyi J, Nagy ZÁ, Érsek T (2006) PCR-based DNA markers for identifying hybrids within Phytophthora alni. J Phytopathol 154:168-177

Baltazár T, Pejchal M, Varga I (2013) Evaluation of European mistletoe (Viscum album L.) infection in the castle park in Lednice. Acta Univ Agric Silvic Mendelianae Brun 59:1565-1574

Benson DA, Karsch-Mizrachi I, Lipman DJ, Ostell J, Sayers EW (2011) GenBank. Nucleic Acids Res 39:D32-37

Bigler C, Bräker OU, Bugmann H, Dobbertin M, Rigling A (2006) Drought as an inciting mortality factor in Scots pine stands of the Valais, Switzerland. Ecosystems 9:330-343

Boose D, Harrison S, Clement S, Meyer S (2011) Population genetic structure of the seed pathogen Pyrenophora semeniperda on Bromus tectorum in western North America. Mycologia 103:85-93

Butt TM, Copping LG (2000) Fungal biological agents. Pestic Outlook 11:186-191

Coates BS, Hellmich RL, Lewis LC (2002) Beauveria bassiana haplotype determination based on nuclear rDNA internal transcribed spacer PCR-RFLP. Mycol Res 106:40-50

Darriba D, Taboada GL, Doallo R, Posada D (2012) jModelTest 2: more models, new heuristic and parallel computing. Nat Methods 9:772

Dobbertin M, Rigling A (2006) Pine mistletoe (Viscum album ssp. austriacum) contributes to to Scots pine (Pinus sys/vestris) mortality in the Rhone valley of Switzerland. For Path 36:309-322 
Dobbertin M, Hilker N, Rebetez M, Zimmermann NE, Wohlgemuth T, Rigling A (2005) The upward shift in altitude of pine mistletoe (Viscum album ssp. austriacum) in Switzerland - the result of climate warming? Int J Biometeorol $50: 40-47$

Edgar RC (2004) MUSCLE: multiple sequence alignment with high accuracy and high throughput. Nucleic Acids Res 32:1792-1797

Farris JS (1989) The retention index and homoplasy excess. Syst Zool 38:406-407

Farris JS, Albert V, Källersjö M, Lipscomb D, Kluge AG (1996) Parsimony jackknifing outperforms neighbor-joining. Cladistics 12:99-124

Fischl G (1996) The leaf-spot disease of mistletoe (Viscum album L.). Növényvédelem 32:181-183

Goloboff PA, Farris JS, Nixon KC (2008) TNT, a free program for phylogenetic analysis. Cladistics 24:774-786

Huelsenbeck JP, Ronquist F (2001) MRBAYES: Bayesian inference of phylogenetic trees. Bioinformatics 17:754-755

Idžojtić M, Pernar R, Glavaš M, Zebec M, Diminić D (2008) The incidence of mistletoe (Viscum album ssp. abietis) on silver fir (Abies alba) in Croatia. Biologia 63:81-85

Iversen J (1944) Viscum, Hedera and Ilex as climate indicators. Geol För Förh Stockh 66:463-483

Jeffree CE, Jeffree EP (1996) Redistribution of the potential geographicalranges of mistletoe and Colorado beetle in Europe in response to the temperature component of climate change. Funct Ecol 10:562-577

Kano R, Hosaka S, Hasegawa A (2004) First isolation of Cryptococcus magnus from cat. Mycopathologia 157:263-264

Karadžić D, Lazarev V, Milenković M (2004) The most significant parasitic and saprophytic fungi on common mistletoe (Viscum album L.) and their potential application in biocontrol. Bull Fac Forest Univ Banja Luka 89:115-126

Kim M-S, Klopfenstein NB, McDonald GI, Arumuganathan K, Vidaver AK (2000) Characterization of North American Armillaria species by nuclear DNA content and RFLP analysis. Mycologia 92:874-883

Kiss L, Pintye A, Kovács GM, Jankovics T, Fontaine MC, Harvey N, Xu X, Nicot PC, Rardin M, Shykoff JA, Giraud T (2011) Temporal isolation explains host-related genetic differentiation in a group of widespread mycoparasitic fungi. Mol Ecol 20:1492-1507

Kluge AG, Farris JS (1969) Quantitative phyletics and the evolution of Anurans. Syst Zool 18:1-32

McNeill J, Barrie FR, Buck WR, Demoulin V, Greuter W, Hawksworth DL, Herendeen PS, Knapp S, Marhold K, Prado J, Prud'homme Van Reine WF, Smith GF, Wiersema JH, Turland NJ (2012) International Code of Nomenclature for algae, fungi, and plants (Melbourne Code) adopted by the Eighteenth International Botanical Congress Melbourne, Australia, July 2011. Regnum Vegetabile 154. Koeltz Scientific Books, Koenigstein, Germany

Nechwatal J, Mendgen K (2009) Evidence for the occurance of natural hybridization in reed-associated Pythium species. Plant Pathol 58:261-270

Nylander JAA, Wilgenbusch JC, Warren DL, Swofford DL (2008) AWTY (are we there yet?): a system for graphical exploration of MCMC convergence in Bayesian phylogenetics. Bioinformatics 24:581-583

Phillips AJL, Alves A, Pennycook SR, Johnston PR, Ramaley A, Akulov A, Crous PW (2008) Resolving the phylogenetic and taxonomic status of dark-spoted teleomorph genera in the Botryosphaeriaceae. Persoonia 21:29-55

Phillips AJL, Alves A, Abdollahzadeh J, Slippers B, Wingfield MJ, Groenwald JZ, Crous PW (2013) The Botryosphaeriaceae: genera and species known from culture. Stud Mycol 76:51-167

Poczai P, Hyvönen J (2010) Nuclear ribosomal spacer regions in plant phylogenetics: problems and prospects. Mol Biol Rep 37:1897-1912

Queloz V, Grünig CR, Bermdt R, Kowalski T, Sieber TN, Holdenrieder O (2011) Cryptic speciation in Hymenoscyphus albidus. For Path 41:133-142

Rydholm C, Szakacs G, Lutzoni F (2006) Low genetic variation and no detectable population structure in Aspergillus fumigatus compared to closely related Neosartorya species. Eukaryotic Cell 5:650-657

Skre O (1979) The regional distribution of vascular plants in Scandinavia with requirements for high summer temperatures. Norw J Bot 26:295-318

Slippers B, Crous PW, Denman S, Coutinho TA, Wingfield BD, Wingfield MJ (2004) Combined multiple gene genealogies and phenotypic characters differentiate several species previously identified as Botryosphaeria dothidea. Mycologia 96:83-101

Stojanović S (1989) The investigation of Sphaeropsis visci (Salm.) Sacc. and Colletotrichum gloeosporoides (Sacc.) Penz., parasite on European mistletoe (Viscum album ssp. typicum Beck). Zaštita Bilja 40:493-503
Stöver BC, Müller KF (2010) TreeGraph2: combining and visualizing evidence from different phylogenetic analyses. BMC Bioinformatics 11:7

Tsopelas P, Angelopoulos A, Economou A, Soulioti N (2004) Mistletoe (Viscum album) in the fir forest of Mount Parnis, Greece. For Ecol Manage 202:59-65

Varga I, Taller J, Baltazár T, Hyvönen J, Poczai P (2012a) Leaf-spot disease on European mistletoe (Viscum album) caused by Phaeobotryosphaeria visci: a potential candidate for biological control. Biotechnol Lett 34:1059-1065

Varga I, Nagy V, Baltazár T, Mátyás KK, Poczai P, Molnár I (2012b) Study of the efficiency of different systemic herbicides against European mistletoe (Viscum album) and their antifungal activity against hyperparasitic mistletoe fungus. Növényvédelem 48:507-517

Varga I, Baltazár T, Apró M, Poczai P, Hyvönen J (2012c) Optimizing conditions for sporulation of European mistletoe hyperparasitic fungus (Phaeobotryosphaeria visci): effect of light and different media. J Agri Sci Debrecen 50:60-66

Varga I, Baltazár T, Pejchal M (2013) Optimization of growing conditions of European mistletoe hyperparasitic fungus (Phaeobotryosphaeria visci): effect of different media and antibiotics. Acta Hort et Regiotecturae 2:44-47

Varga I, Poczai P, Tiborcz V, Aranyi NR, Baltazár T, Bartha D, Pejchal M, Hvvönen J (2014) Changes in the distribution of the European mistletoe (Viscum album L.) in Hungary during the last hundred years. Folia Geobot, in press

von Tubeuf KF (1923) Monographie der Mistel. Oldenbourg, München, Berlin

Wang Y, Prosen DE, Mei L, Sullivan JC, Finney M, Vander Horn PB (2004) A novel strategy to engineer DNA polymerases for enhanced processivity and improved performance in vitro. Nucleic Acids Res 32:1197-1207

White TJ, Bruns T, Lee S (1993) Amplification and direct sequencing of fungal ribosomal RNA genes for phylogenetics. In: Innis MA, Gelfand HD, Sninsky JJ (eds) PCR protocol: a guide to methods and applications. Academic Press, San Diego, pp 315-322

Zillig W, Stetter KO, Wunderl S, Schultz W, Priess H, Scholz I (1980) The Sulfolobus "Caldariella" group: taxonomy on the basis of the structure of DNA-dependent RNA polymerases. Arch Microbiol 125:259-269

Zuber D (2004) Biological flora of Central Europe: Viscum album L. Flora 199:181-203

Zuber D, Widmer A (2000) Genetic evidence for host specificity in the hemi-parasitic Viscum album L. (Viscaceae). Mol Ecol 9:1069-1073

\section{doi:10.1186/2193-1801-3-569}

Cite this article as: Varga et al:: Application of direct PCR in rapid rDNA ITS haplotype determination of the hyperparasitic fungus Sphaeropsis visci (Botryosphaeriaceae). SpringerPlus 2014 3:569.

\section{Submit your manuscript to a SpringerOpen ${ }^{\odot}$ journal and benefit from:}

- Convenient online submission

- Rigorous peer review

- Immediate publication on acceptance

- Open access: articles freely available online

- High visibility within the field

- Retaining the copyright to your article

Submit your next manuscript at $>$ springeropen.com 